\title{
Osteoid Osteoma of the Maxilla: Literature Review and Case Report
}

\author{
Roscher DF ${ }^{*}$, Belossi ME $\mathrm{ME}^{1}$ Paparella $\mathrm{ML}^{2}$ and \\ Stolbizer $\mathbf{F}^{1}$ \\ ${ }^{1}$ Department of Oral and Maxillofacial Surgery, School of \\ Dentistry, University of Buenos Aires, Argentina \\ ${ }^{2}$ Department of Oral Pathology, School of Dentistry, \\ University of Buenos Aires, Argentina \\ *Corresponding author: Daniel Roscher, School of \\ Dentistry, University of Buenos Aires, Marcelo T. Alvear, \\ CABA, Buenos Aires, Argentina
}

Received: January 09, 2018; Accepted: February 13, 2018; Published: March 01, 2018

\begin{abstract}
Osteoid osteoma $(\mathrm{OO})$ is a benign osteogenic tumor, usually less than $2 \mathrm{~cm}$ in size. It is associated with nocturnal pain, and in most cases, is alleviated with non-steroidal anti-inflammatory drugs (NSAIDs). It usually presents in the first three decades of life, and is predominant in men. Osteoid osteoma usually affects long bones, and rarely occurs in the jaws. When it does, it is mostly localized in the mandible. Differential diagnosis of $\mathrm{OO}$ includes fibroosseous lesions, tumors of osseous origin, and odontogenic tumors. Because of overlapping and superimposition of anatomical structures on conventional radiographs, it is difficult to visualize the architecture of this type of lesion using radiography. Cone beam computerized tomography allows observing the different planes of the lesion, without superimposed structures, and should therefore be the method of choice to analyze jaw lesions suspicious for $\mathrm{OO}$. We herein present a case of $\mathrm{OO}$ in the maxilla, which brings the total number of reported cases to six.
\end{abstract}

Keywords: Osteoid osteoma; Jaws; Pain

\section{Introduction}

Osteoid osteoma (OO) is a benign osteogenic tumor, which is usually less than $2 \mathrm{~cm}$ in size. It is associated with nocturnal pain, and in most cases, is alleviated with non-steroidal anti-inflammatory drugs (NSAIDs). It usually presents in the first three decades of life, and is predominant in men [1,2]. Osteoid osteoma accounts for $12 \%$ of benign skeletal bone tumors [3], and usually affects lower limb long bones, like the femur (40\%), tibia and fibula. Location in the humerus and vertebrae is also frequent $[3,4]$. Less than $1 \%$ of OOs affect the jaws. In these cases, the lingual aspect and lower border of the mandible are usually affected [5]. Osteoid osteoma can present a diagnostic challenge since it has the same clinical, radiographic, and histologic features as other lesions, such as osteoblastoma, cementoblastoma, osteosarcoma, and fibro-osseous lesions $[6,7]$.

Imaging studies are critical to the diagnosis of this pathology. Radiographically, the tumor presents a rounded or oval radiolucent area, the "nidus", surrounded by a radiopaque rim corresponding to a peripheral sclerotic reaction zone. The "nidus" may also be surrounded by a radiolucent halo $[3,8,9]$.

The first description of osteoid osteoma was made by Berg strand in 1930. The author reported two cases: one in the metatarsal and the other case in the phalanx of a finger. Clinically, both were thought to be osteogenic sarcoma; the metatarsal was resected and the finger was amputated. The detailed clinical features and photomicrograph left no doubt about the identity of the lesions, which were interpreted as rare benign osteoblastic lesions, and were attributed to embryonic rests [10].

Although osteoid osteoma had been reported as "chronic bone abscess", "non suppurative sklerosing osteomyelitis", and "osteomyelitis with annular sequestrum", Jaffe is due the credit for establishing it as a distinct entity in 1935. In his original report, Jaffe studied five cases of $\mathrm{OO}$ and evaluated all their clinical and histopathological features. The author identified certain features that were common to all the cases of OO he included in his study: 1) all patients were adolescents or young adults; 2) the presenting complaint was pain, which increased during the night; 3) radiographically, all lesions were rounded and well delimited; 4) the lesions were small and similar in size; 5) surgical excision was performed in all cases on the assumption that the lesion was inflammatory - osteomyelitis or abscesses - although there was no evidence of infection in any of the cases; 6) excision of the lesion resulted in disappearance of all symptoms without recurrence of the local condition [11].

In 1945, Jaffe reported 62 proven and treated cases, and confirmed most of the features of the tumor he had reported in his first publication on 5 cases in 1935. In 1966, Eideken identified three types of osteoid osteoma, the cortical, medullary, and subperiosteal type, depending on the radiographic location of the nidus, and found the cortical type to be the most common [13].

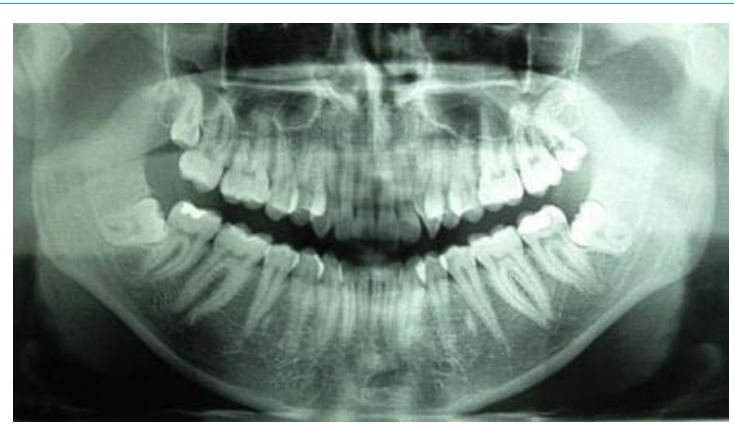

Figure 1: Panoramic radiograph. The image does not allow clear visualization of the lesion.
Citation: Roscher DF, Belossi ME, Paparella ML and Stolbizer F. Osteoid Osteoma of the Maxilla: Literature Review and Case Report. J Dent App. 2018; 5(1): 399-402. 
Table 1: Review of the literature of case reports of osteoid osteoma in the maxillofacial region.

\begin{tabular}{|c|c|c|c|c|c|c|}
\hline Case & Author/Year & Age & Sex & Location & Size & Symptoms \\
\hline 1 & Rushton (1951) [14] & 27 & M & Mandible & $6 \mathrm{~mm}$ & Pain \\
\hline 2 & Foss (1955) [29] & 26 & $\mathrm{~F}$ & Mandible & $5 \mathrm{~mm}$ & Pain \\
\hline 3 & Nelson (1955) [18] & 17 & M & Mandible & $25 \mathrm{~mm}$ & Pain \\
\hline 4 & Stoopack (1958) [19] & 25 & M & Mandible & - & No \\
\hline 5 & Lind (1964) & 48 & M & Mandibular condyle & $3 \mathrm{~mm}$ & Pain \\
\hline 6 & Hillman (1965) [20] & 4 & $\mathrm{~F}$ & Maxilla & - & No \\
\hline 7 & Borello (1967) [30] & 21 & M & Maxilla & $30 \times 20 \mathrm{~mm}$ & No \\
\hline 8 & Greene (1968) [31] & 45 & $\mathrm{~F}$ & Maxilla & $10 \mathrm{~mm}$ & Pain \\
\hline 9 & Brynolf (1969) [32] & 77 & M & Maxilla & $4 \mathrm{~mm}$ & No \\
\hline 10 & Gupta (1985) [33] & 18 & $\mathrm{~F}$ & Mandible & $30 \mathrm{~mm}$ & Pain \\
\hline 11 & Zulian (1987) [34] & 17 & $\mathrm{~F}$ & Mandible & $10 \mathrm{~mm}$ & Pain \\
\hline 12 & Tochihara (2001) [35] & 21 & $\mathrm{~F}$ & Mandibular condyle & $8 \mathrm{~mm}$ & Pain \\
\hline 13 & Liu (2002) [36] & 18 & M & Mandible & $12 \mathrm{~mm}$ & Pain \\
\hline 14 & Ida (2002) [37] & 26 & $\mathrm{~F}$ & Mandible & $5 \times 10 \mathrm{~mm}$ & Pain \\
\hline 15 & Badauy (2007) [38] & 26 & M & Mandible & $8 \mathrm{~mm}$ & Pain \\
\hline 16 & do Egito Vasconcelos (2007) [39] & 23 & $\mathrm{~F}$ & Mandibular condyle & $8 \times 11 \mathrm{~mm}$ & Pain \\
\hline 17 & Rahsepar (2009) [40] & 21 & M & Mandible & $6 \times 8 \mathrm{~mm}$ & Pain \\
\hline 18 & Manjunatha (2009) [41] & 18 & $\mathrm{~F}$ & Mandible & $10 \mathrm{~mm}$ & Pain \\
\hline 19 & Walia (2010) [42] & 18 & M & Mandible & $10 \times 20 \mathrm{~mm}$ & Pain \\
\hline 20 & Karandikar (2011) [21] & 14 & M & Mandible & $35 \mathrm{~mm}$ & No \\
\hline 21 & Singh (2012) [8] & 20 & M & Mandible & $35 \mathrm{~mm}$ & Pain \\
\hline 22 & Mohammed (2013) [7] & 20 & - & Mandible & $30 \mathrm{~mm}$ & Pain \\
\hline 25 & Khaitan (2016) [5] & 40 & M & Maxilla // Upper jaw & $10 \times 20 \mathrm{~mm}$ & Pain \\
\hline 26 & Maccotta (2016) [9] & 20 & M & Mandible & $10 \mathrm{~mm}$ & Pain \\
\hline 27 & Martin (2016) [6] & 14 & M & Mandible & $17 \mathrm{~mm}$ & No \\
\hline 28 & Raja Devathambi (2016) [43] & 13 & $\mathrm{~F}$ & Mandible & $10 \mathrm{~mm}$ & Pain \\
\hline 29 & Infante-Cossio (2017) [44] & 44 & $\mathrm{~F}$ & Mandible & $10 \mathrm{~mm}$ & Pain \\
\hline 30 & Our case (2017) & 21 & M & Maxilla & $4 \mathrm{~mm}$ & Pain \\
\hline
\end{tabular}

Osteoid osteoma of the maxillofacial region is very rare. It was first described by Rushton et al. in 1951; the authors reported a 27 -year-old male patient presenting a $6 \mathrm{~mm}$ lesion on the mandibular alveolar ridge associated with the lower first molar [14]. Since that first report, only 29 cases of $\mathrm{OO}$ in the jaws (Table 1) have been reported, $83 \%$ of which were located in the mandible and $17 \%$ in the maxilla. Unlike OO in the remaining skeletal areas, no sex predilection was observed in the reported cases of OO in the jaws. Two of 29 cases were multifocal $[15,16]$.

When $\mathrm{OO}$ is located in the jaws, it is necessary to establish differential diagnosis from fibro-osseous lesions, bone tumors, and odontogenic tumors. The main differential diagnosis is from osteoblastoma. Although they are very similar lesions, osteoblastoma is usually larger9. Treatment of choice for $\mathrm{OO}$ in the jaws is enucleation, since it eliminates the pain. Recurrence is infrequent, and is usually due to incomplete excision of the tumor [1,9].

\section{Case Presentation}

A twenty-one year old male patient presented at the Oral Maxillofacial Surgery and Traumatology Department of the School of Dentistry, University of Buenos Aires, with a $6 \mathrm{~mm}$ diameter swelling and intense pain in the buccal aspect of the alveolar ridge at the level of the right upper second premolar. The mucosa covering the lesion appeared normal. Panoramic radiograph revealed a radiopaque mass. Cone beam computerized tomography showed a radiopaque lesion measuring $5 \mathrm{~mm}$ in diameter, with a radiolucent core and peripheral reactive sclerosis (Figure 2).

Under local anesthesia, the lesion was enucleated and the cavity was burred. The patient reported total remission of pain after surgery.

The histopathological study of the surgical specimen showed formation of immature bone trabeculae with marked cellularity and lined by plump epithelioid-like osteoblasts separated by highly 


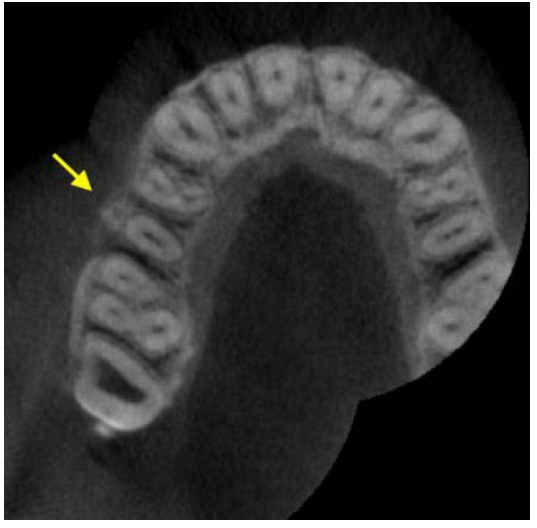

Figure 2: СВСТ axial section. Note the well demarcated lesion on the buccal plate of the maxilla at the level of the second upper right premolar.

vascular, edematous and congested fibrous stroma; osteoclast-like giant multinucleated cells were also found. Thinning of the cortical bone was observed in some areas of the periphery (Figure 3). The histopathological study of the lesion together with the clinical and radiographic data confirmed diagnosis of osteoid osteoma. The patient was followed up post-operatively, and had no signs or symptoms of recurrence.

\section{Discussion}

The etiopathogenesis of osteoid osteoma is controversial. Some authors consider it to be a neoplasm, while others consider it as an inflammatory reaction. Although the traumatic etiology of osteoid osteoma has not been demonstrated to date, there are reports of the lesion occurring following trauma [18-21]. Genetic changes in OO have been scantily studied, and few cases have been reported in the literature [22].

The lesion is usually associated with severe pain that increases during the night and is relieved by NSAIDs. The tumor has been shown to have high levels of prostaglandins, especially PGE2 and PGI2, and abundant nerve fibers within the nidus, which would explain the presence of pain $[23,24]$.

Several authors have suggested that osteoid osteoma and osteoblastoma have the same origin and are of the same nature [25]. Both are typically seen in the second decade of life, with a marked male predilection. They also have similar histological features, showing increased osteoid tissue formation surrounded by vascular fibrous stroma and perilesional sclerosis. Nevertheless, they also have distinct characteristics. The main difference is that osteoblastomas are usually larger than OO, exceeding $20 \mathrm{~mm}$ in diameter [26,27]. Osteoid osteoma usually occurs in long bones, like the femur and the tibia, presents with pain that increases at night, and is relieved with NSAIDs. Osteoblastoma, on the other hand, is more frequently located in the axial skeleton; the pain is not worse at night and is less likely to be relieved with NSAIDSs. Osteoblastoma can be locally aggressive, whereas OO has limited growth potential [26]. There are some case reports of osteoid osteoma that recurred as an osteoblastoma after surgery $[25,28]$.

Osteoid osteoma of the jaws is very rare. Twenty-four (83\%)

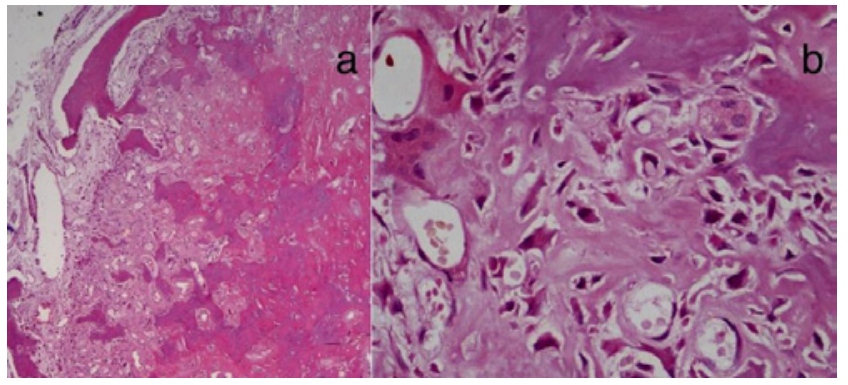

Figure 3: Histological section of the lesion. a) Bone trabeculae and osteoid with a cellular vascular fibrous stroma. Peripherally, cortical with reduced thickness and fenestration. H-E Orig. Mag. x10. b) Osteoblasts with immature bone and isolated osteoclasts. H-E Orig. Mag. x40.

of the 29 reported cases were located in the mandible, and only 5 (17\%) were located in the maxilla. The case reported here brings the world series of OO of the maxilla to 6 cases [29]. Because of overlapping and superimposition of anatomical structures on conventional radiographs, it is difficult to visualize the architecture of this type of lesion using radiography. Cone beam computerized tomography (BCCT) allows different spatial views of the lesion, with no superimposition of structures, and should therefore be the method of choice to observe lesions suspicious for OO of the jaws.

\section{References}

1. El-Naggar AK, Chan JK, Grandis JR, Takata T, Slootweg PJ. WHO classification of head and neck tumours. $4^{\text {th }}$ Ed. IARC: Lyon. 2017.

2. Fletcher CDM, Bridge JA, Hogendoorn PCW, Mertens F. WHO classification of tumours of soft tissue and bone. $4^{\text {th }}$ Ed. IARC: Lyon. 2013.

3. Kransdorf MJ, Stull MA, Gilkey FW, Moser RP. From the archives of AFIP. Osteoid osteoma. Radiographics. 1991; 11: 671- 696.

4. Healey JH, Ghelman B. Osteoid Osteoma and Osteoblastoma. Current Concepts and Recent Advances. Clin Orthop Relat Res. 1986; 204: 76-85.

5. Khaitan T, Ramaswamy P, Ginjupally U, \& Kabiraj A. A Bizarre Presentation of Osteoid Osteoma of Maxilla. Iran J Pathol. 2016; 11: 431-434.

6. Martin L, Kennedy G, Thorne L, Ayliffe P, Speight PM. An unusual case of osteoid osteoma occurring simultaneously with an ameloblastoma: a case report. Oral Surgery. 2017; 10: 100-104.

7. Mohammed I, Jannan NA, Elrmali A. Osteoid osteoma associated with the teeth: unusual presentation. Int J Oral Maxillofac Surg. 2013; 42: 298-302.

8. Singh A, Solomon MC. Osteoid osteoma of the mandible: a case report with review of the literature. J Dent Sci. 2017; 12: 185-189.

9. Maccotta M, Ung L, Roche Y. Osteoid osteoma of the mandible: a case report and review of the literature. Med Buccale Chir Buccale. 2016; 22: 317-323.

10. Sherman MS. Osteoid osteoma: review of the literature and report of thirty cases. J Bone Joint Surg. 1947; 29: 918-930

11. Jaffe HL. "Osteoid osteoma": a benign osteoblastic tumor composed of osteoid and atypical bone. Arch Surg. 1935; 31: 709-728.

12. Jaffe HL. Osteoid-osteoma of bone. Radiology. 1945; 45: 319-334.

13. Edeiken J, Depalma AF, Hodes PJ. Osteoid Osteoma (Roentgenographic Emphasis). Clin Orthop Relat Res. 1966; 49: 201-208.

14. Rushton MA. An osteoid-osteoma of the mandibular alveolus. Oral Surg Oral Med Oral Pathol. 1951; 4: 86-88.

15. An SY, Shin HI, Choi KS, Park JW, Kim YG, Benavides E, et al. Unusual osteoid osteoma of the mandible: report of case and review of the literature. Oral Surg Oral Med Oral Pathol Oral Radiol. 2013; 116: e134-e140. 
16. Adouly T, Oubahmane T, Adnane C, Rouadi S, Abada R, Roubal M, et al Bilateral osteoid osteoma of the mandible: An unusual case report. Int $\mathrm{J}$ Pediatr Otorhinolaryngol Extra. 2015; 10: 56-58.

17. Depeyre A, Brygo A, Leroy X, Gryselein R, Ferri J. Osteoid osteoma of zygomatic bone: Case report and literature review. Rev Stomatol Chir Maxillofac Chir Orale. 2016; 117: 442-445.

18. Nelson AR. Osteoid osteoma of maxilla. AMA Arch Surg. 1955; 70: 459-461.

19. Stoopack JC. Sialolith and osteoid osteoma. Oral Surg Oral Med Oral Pathol. 1958; 11: 1220-1225

20. Hillman BS, Birck HG. Osteoid osteoma of the maxilla in a four-year-old patient. Laryngoscope. 1965; 75: 1872-1876.

21. Karandikar S, Thakur G, Tijare M, Shreenivas K, Agrawal K. Osteoid osteoma of mandible. BMJ Case Rep. 2011; 1-4.

22. Baruffi MR, Volpon JB, Neto JB, Casartelli, C. Osteoid osteomas with chromosome alterations involving 22q. Cancer genet cytogenet. 2001; 124 127-131.

23. Mungo DV, Zhang X, O'Keefe RJ, Rosier RN, Puzas JE, Schwarz EM. COX-1 and COX-2 expression in osteoid osteomas. J Orthop Res. 2002; 20: 159162.

24. Laurence N, Epelman M, Markowitz RI, Jaimes C, Jaramillo D, Chauvin NA Osteoid osteomas: a pain in the night diagnosis. Pediatr radiol. 2012; 42 1490-1501.

25. Sung HW, Liu CC. Can osteoid osteoma become osteoblastoma?. Arch Orthop Trauma Surg. 1979; 95: 217-219.

26. Atesok KI, Alman BA, Schemitsch EH, Peyser A, Mankin H. Osteoid osteoma and osteoblastoma. J Am Acad Orthop Surg. 2011; 19; 678-689.

27. Jones AC, Prihoda TJ, Kacher JE, Odingo NA, Freedman PD. Osteoblastoma of the maxilla and mandible: a report of 24 cases, review of the literature, and discussion of its relationship to osteoid osteoma of the jaws. Oral Surg Oral Med Oral Pathol. 2006; 102: 639-650.

28. Chotel F, Franck F, Solla F, Dijoud F, Kohler R, Berard J, et al. Osteoid osteoma transformation into osteoblastoma: fact or fiction?. Orthop Traumato Surg Res. 2012; 98: S98-S104.

29. Foss EL, Dockerty MB, Good CA. Osteoid osteoma of the mandible: report of a case. Cancer. 1955; 8: 592-594.

30. Borello ED, Sedano HO. Giant osteoid osteoma of the maxilla: Report of a case. Oral Sur Oral Med Oral Pathol. 1967; 23: 563-566.
31. Greene GW Jr, Natiella JR, Spring PN Jr. Osteoid osteoma of the jaws: Report of a case. Oral Surg Oral Med Oral Pathol. 1968; 26: 342-351.

32. Brynolf I. Osteoid osteoma and fibrous dysplasia in the periapical region of maxillary incisors. Report of three cases. Oral Surg Oral Med Oral Pathol. 1969; 28: 243-248

33. Gupta OP, Jain RK, Agarwal MK, Khanna S, Shrivastava A. Osteoid osteoma of the mandible. Ear Nose Throat J. 1985; 64: 206-208.

34. Zulian MA, Vincent SK, Hiatt WR. Osteoid osteoma of the mandibular ramus. J Oral Maxillofac Surg. 1987; 45: 712-714

35. Tochihara S, Sato T, Yamamoto H, Asada K, Ishibashi K. Osteoid osteoma in mandibular condyle. Int J Oral Maxillofac Surg. 2001; 30: 455-457.

36. Liu CJ, Chang KW, Chang KM, Cheng CY. A variant of osteoid osteoma of the mandible: report of a case. J Oral Maxillofac Surg

37. Ida M, Kurabayashi T, Takahashi Y, Takagi M, Sasaki T. Osteoid osteoma in the mandible. Dentomaxillofac Radiol. 2002; 31: 385-387.

38. Badauy C, Carrard V, Rados P, Sant'ana Filho M. Radiopaque mass of the posterior mandible with lingual expansion. J Oral Maxillofac Surg. 2007; 65 : 2498-2502.

39. do Egito Vasconcelos BC, Porto GG, Bessa-Nogueira RV. Rare benign tumors of the mandibular condyle: report of 2 cases and literature review. J Oral Maxillofac Surg. 2007; 65: 1830-1835.

40. Rahsepar B, Nikgoo A, Fatemitabar SA. Osteoid osteoma of subcondylar region: case report and review of the literature. J Oral Maxillofac Surg. 2009; 67: 888-893.

41. Manjunatha BS, Nagarajappa D. Osteoid osteoma. Indian J Dent Res. 2009 20: $514-515$

42. Walia C, Devi $P$, Thimmarasa VB, Jayadev S. Osteoid osteoma of the mandible: A rare entity. J Indian Acad Oral Med Radiol. 2010; 22: 162.

43. Devathambi TJR, Ambrose WC, Niazi KZTM, Raja S. Osteoid osteoma in anterior border of ramus of mandible: A rare entity. J Ind Acad Oral Med Radiol. 2016; 28: 449-452.

44. Infante-Cossio P, Restoy-Lozano A, Espin-Galvez F, Gonzalez-Perez LM Mandibular Osteoid Osteoma. J Emer Med. 2017; 52: e83-e84.
J Dent App - Volume 5 Issue 1 - 2018

ISSN : 2381-9049 | www.austinpublishinggroup.com

Roscher et al. @ All rights are reserved
Citation: Roscher DF, Belossi ME, Paparella ML and Stolbizer F. Osteoid Osteoma of the Maxilla: Literature Review and Case Report. J Dent App. 2018; 5(1): 399-402. 